\title{
Pituitary Gland Adenoma
}

National Cancer Institute

\section{Source}

National Cancer Institute. Pituitary Gland Adenoma. NCI Thesaurus. Code C3329.

A non-metastasizing tumor that arises from the adenohypophysial cells of the anterior lobe of the pituitary gland. The tumor can be hormonally functioning or not. The diagnosis can be based on imaging studies and/or radioimmunoassays. Due to its location in the sella turcica, expansion of the tumor mass can impinge on the optic chiasm or involve the temporal lobe, third ventricle and posterior fossa A frequently associated physical finding is bitemporal hemianopsia which may progress to further visual loss. 